\title{
Five decades of shrinkage of July 1st glacier, Qilian Shan, China
}

\author{
Akiko SAKAI, ${ }^{1}$ Koji FUJITA, ${ }^{1}$ Keqin DUAN, ${ }^{2}$ Jianchen PU, ${ }^{2}$ Masayoshi NAKAWO, ${ }^{3}$ \\ Tandong $\mathrm{YAO}^{4}$ \\ ${ }^{1}$ Graduate School of Environmental Studies, Hydrospheric-Atmospheric Research Center, Nagoya University, \\ Nagoya 464-8601, Japan \\ E-mail: shakai@ihas.nagoya-u.ac.jp \\ ${ }^{2}$ Cold and Arid Regions Environmental and Engineering Research Institute, Chinese Academy of Sciences, \\ 260 Donggang West Road, Lanzhou 730000, China \\ ${ }^{3}$ Research Institute for Humanity and Nature, 457-4, Kamigamo-motoyama, Kita-ku, Kyoto 603-8047, Japan \\ ${ }^{4}$ Institute of Tibetan Plateau Research, Chinese Academy of Sciences, Beijing 100085, China
}

\begin{abstract}
A survey of July 1st glacier, Qilian Shan, China, was carried out in 2002. Previously, the glacier's boundary had been recorded in 1956, and further research had been carried out in the mid1970s and 1980s. Our survey reveals that area shrinkage and surface lowering have accelerated in the past 15 years. Surface elevation changes can result from changes in accumulation, surface melting and emergence velocity. The contributions of these elements to surface lowering are evaluated at the lower part of the glacier from observations of surface velocity, ice thickness and precipitation, and from temperature data near the glacier. Apart from the effect of glacier ice redistribution, our analysis reveals quantitatively that the recent accelerated glacier shrinkage has been caused by increasing temperature. Furthermore, it is established that meltwater discharge from the glacier in the past 17 years has increased due to glacier shrinkage, by about $50 \%$ over that from 1975 to 1985 .
\end{abstract}

\section{INTRODUCTION}

The world's mountain glaciers act as water reservoirs, influencing the climate and water regime around the Earth (Babkin and Klige, 2003). Water from glaciers contributes to sea-level changes (Meier, 1984; Warrick and Oerlemans, 1990; Church and others, 2001; Braithwaite and Raper, 2002), and glaciers in arid inland areas serve as important water reservoirs (Fountain and Tangborn, 1985; Liu and others, 2003).

The Qilian Shan are located on the northern fringe of the Tibetan Plateau. These mountains have a total of 2815 glaciers, occupying about $1930 \mathrm{~km}^{2}$ (Tsvetkov and others, 1998). This area has relatively high precipitation $\left(>300 \mathrm{~mm} \mathrm{a}^{-1}\right.$ ) at high elevations (Ding and Kang, 1985; Zhu and Wang, 1996), but little precipitation $\left(<50 \mathrm{~mm} \mathrm{a}^{-1}\right)$ downstream along the Heihe river (Wang and Cheng, 1999) shown in Figure 1. Thus, people living in this area are confined to several oasis cities at the foot of the Qilian Shan, with the Gobi Desert extending downstream of these cities. Since ancient times, meltwater from glaciers and snow on these mountains has provided city dwellers with drinking water and irrigation. Therefore, mountain snow and glaciers are important water resources in this area (Wang and Cheng, 1999). Similar oasis cities came into existence along the Silk Road, where European and Asian cultures met, so water from the Qilian Shan has long supported EastWest cultural exchanges.

July 1st glacier, Qilian Shan, is located in inland China, so its thermal regime is of polar type (Huang, 1990), with low ice temperature $\left(-6^{\circ} \mathrm{C}\right.$ in August in the 1970s; Xie and others, 1985a). Some of the meltwater refreezes in the snow layer, and it is necessary to take this surface refreezing into account in order to estimate the mass balance of such glaciers (Fujita and others, 1996; Fujita and Ageta, 2000).

Glaciers fluctuate with climate change, and the relation between the two has been studied by many researchers (e.g. Pelto, 1987; Braithwaite and Zhang, 1999). The mass of some glaciers (mainly in Scandinavia) has increased in recent years because of high precipitation and cool summers (Haeberli and others, 1998), while many other glaciers have shrunk (Haeberli and others, 1998). Kamchatka glaciers have shrunk since precipitation has declined (Yamaguchi, 2003), and the glaciers in central Asia are shrinking due to both increasing temperature and decreasing precipitation (Khromova and others, 2003).

E. Kang and others (unpublished information) forecast the runoff from the Qilian Shan area up to 2040 under the assumption of increasing temperature. Liu and others (2003) estimated the glacier runoff from the Little Ice Age to 1990. However, their estimates were based on glacier fluctuations only until the 1990s, without the benefit of more recent data.

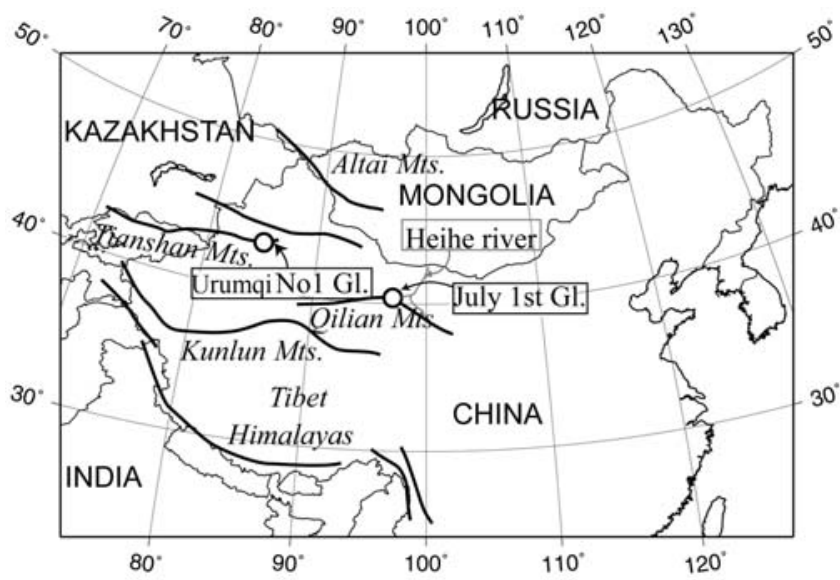

Fig. 1. Location of July 1st glacier in the Qilian Shan, and UG1 in the Tien Shan. Gray line shows Heihe river, which flows from the Qilian Shan. Thick lines represent mountain ranges; thin lines indicate international borders. 


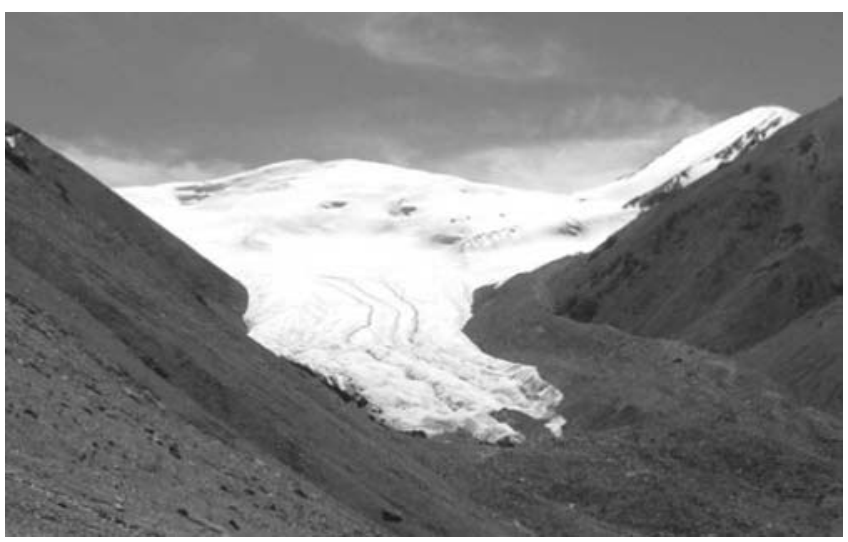

Fig. 2. Photograph of July 1st glacier taken in September 2003.

The aims of this study are (i) to summarize glacier fluctuations from data gathered over the past 50 years, (ii) to elucidate quantitatively the relation between climate change and glacier fluctuation, and (iii) to evaluate variations in meltwater discharge from July 1 st glacier.

\section{LOCATION AND PAST RECORDS}

A survey of the glacier boundary and surface elevation was carried out on July $1 \mathrm{st}$ ('Qiyi' in Chinese) glacier $\left(39^{\circ} 15^{\prime} \mathrm{N}\right.$, $97^{\circ} 45^{\prime} \mathrm{E}$; 4295-5088ma.s.l.; Fig. 1). Figure 2 shows a photograph taken from downstream of the glacier, which is located on the northern slope of the Qilian Shan with its terminus facing north.

A map of the glacier with contour intervals of $50 \mathrm{~m}$ (Xie and others, 1985b) was made in 1975 from photographic survey data. It also includes the end-moraine area. Comparison of the 1975 map with the 1956 map (Xie and others, 1985b) shows that the average retreat rate of the terminus was about $2 \mathrm{ma}^{-1}$ from 1956 to 1975 , and that the total glacier area has decreased by $0.024 \mathrm{~km}^{2}$ since 1956 .

Liu and others (1992) conducted a re-survey of the ablation area in 1985, reporting that the terminus had retreated at a rate of about $1 \mathrm{ma}^{-1}$, and that the glacial area had decreased by $0.0047 \mathrm{~km}^{2}$ since 1975 . Over this decade, the glacier's surface elevation decreased at altitudes below $4500 \mathrm{~m}$, yet increased by an average of $8 \mathrm{~m}$ at altitudes of 4580-4620 m.

Dyurgerov (2002) showed that the equilibrium-line altitude was at $4550-4710 \mathrm{~m}$ in the mid-1970s and 1980s. There are also surface velocity data from 1976 to 1977 (Sun and Huang, 1985) and from 1984 to 1985 (Song and others, 1992) for the lower portion of the glacier (up to 4850 m a.s.I.). In 1977, Su measured the glacial ice thickness up to $4850 \mathrm{~m}$ a.s.l. using the gravitational method (Su, 1985).

\section{OBSERVATIONS}

The 2002 survey was carried out by global positioning system (GPS; AmTechs Co., Ltd) to a horizontal and vertical accuracy of better than $10 \mathrm{~mm}$. Unfortunately, the control points established in 1975 and 1985 were not found in 2002. The ridge on the left side of the moraine had a distinct shape represented in the 1975 map made by Xie and others (1985b). This was therefore remeasured by GPS in 2002, and its shape matched that in the 1975 map, indicating that the ridge had not changed significantly since 1975 . The

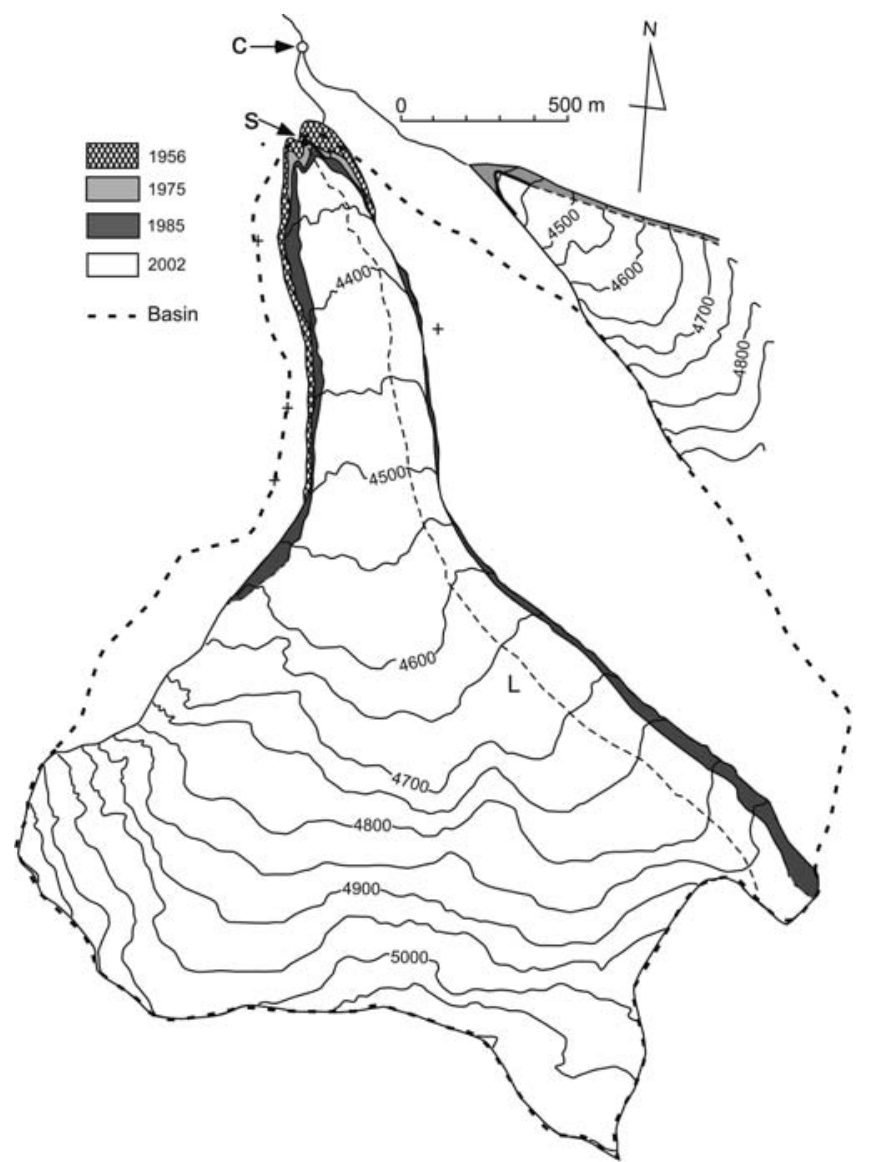

Fig. 3. Boundaries of July 1st glacier in 1956, 1975, 1985 and 2002. Note the glacier on the east side of July 1st glacier, which shows only the data as of 1975 . Contours at intervals of $50 \mathrm{~m}$ represent those surveyed in 1975. Surface lowering was surveyed by GPS along the approximate flowline $L$ in 2002 . The + mark indicates the control points for the survey conducted in 2002.

difference between the relative heights of each control point in 2002 and 1975 was $<10 \mathrm{~m}$. Stake surveys were carried out in September 2003 and September 2004, and the surface velocity distribution was obtained over the 1 year period.

The relative height of the moraine was measured by GPS in 2004 to compare with that surveyed in 1975. The difference was $<1 \mathrm{~m}$, confirming that the moraine height had hardly changed since 1975 .

\section{RESULTS}

\section{Horizontal shrinkage}

The retreat of the glacier boundaries in 1956, 1975, 1985 and 2002 is summarized in Figure 3. The glacier boundary in 1956 and the glacier surface elevation in 1975 (including that of a glacier located to the east of July 1 st glacier) were reported by Shi and others (1988). The glacier boundary in 1985 was reported by Liu and others (1992). It is clear from Figure 3 that the glacier retreated between 1956 and 2002. Xie and others (1985b) and Liu and others (1992) concluded that the average retreat rate of the glacier terminus was about $2 \mathrm{~m} \mathrm{a}^{-1}$ from 1956 to 1975 , and about $1 \mathrm{~m} \mathrm{a}^{-1}$ from 1975 to 1985 . Based on our observations, we determined an average retreat rate of the terminus of $1.1 \mathrm{~m} \mathrm{a}^{-1}$ from 1985 to 2002. The retreat rate was very rapid from 1956 to 1975 and has decreased and remained almost constant since then. 


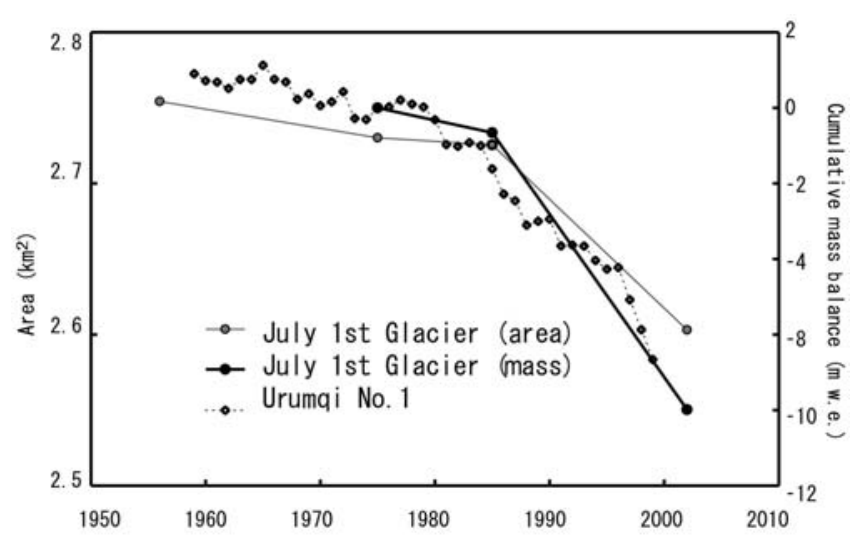

Fig. 4. Areal changes in July 1 st glacier, 1956-2002, and cumulative net mass balances since 1975 of July 1 st glacier and UG1. Cumulative net mass balance at UG1 is plotted with the value in 1975 set to zero.

Changes in glacier area since 1956 are summarized in Figure 4. The area in 2002 had decreased by 5\% since 1956 (46 years), and by 4\% since 1985 (17 years). Although there is evidence for a decrease in the shrinkage rate between 1975 and 1985, the long-term shrinkage rate has accelerated over the last 17 years and is currently at its highest since 1956.

\section{Surface lowering}

Since our measurements show that the height of the end moraine (relative height between confluence of the river (point C) and point S in Fig. 3) has not changed since 1975, point $S$ at the glacier terminus was chosen as a control point. Longitudinal surface profiles in 1975, 1985 and 2002, along the approximate flowline $\mathrm{L}$ in Figure 3, are shown in Figure 5. Glacier thinning has mainly occurred near the terminus, reaching a maximum of $40 \mathrm{~m}$ since 1975. No surface elevation data higher than 4650 ma.s.l. were available in 1985. However, surface lowering from 1975 to 1985 can be assumed to be zero, and in the upper area (above $4700 \mathrm{ma.s.l}$.) there was virtually no change from 1975 to 2002. Measured surface lowering was greater at $4300-4400 \mathrm{~m}$ a.s.I. than at $4400-4450 \mathrm{~m}$ a.s.l.

The average surface lowering rates of the glacier area were $0.06 \mathrm{~m} \mathrm{a}^{-1}$ for $1975-85$, and $0.38 \mathrm{~m} \mathrm{a}^{-1}$ for $1985-2002$, assuming the surface lowering rate along line $L$ was uniform at each elevation, and that no surface elevation change occurred above 4850 ma.s.l. from 1975 to 2002. Thus, the surface lowering rate has accelerated over the past 17 years, and volumes lost from the glacier (deduced from the surface lowering and area change) were $1.5 \times 10^{6} \mathrm{~m}^{3}$ for $1975-85$, and $16.9 \times 10^{6} \mathrm{~m}^{3}$ for $1985-2002$.

The glacier area shrinkage rate decreased once between 1975 and 1985, as shown in Figure 4, consistent with the relatively low surface lowering rate in those years.

Ürümqi glacier No. 1 (UG1), located in the east Tien Shan, northwest China $\left(43^{\circ} 05^{\prime} \mathrm{N}, 86^{\circ} 49^{\prime} \mathrm{E}\right)$, about $1000 \mathrm{~km}$ west of July 1 st glacier (Fig. 1), is the only glacier in China that has been monitored continuously since the 1950s. Figure 4 shows the cumulative net mass balance since 1975 of July 1 st glacier and UG1. The mass balance, in water equivalent, of July 1 st glacier (1956-75, 1975-85 and 19852002) was deduced assuming an ice density of $900 \mathrm{~kg} \mathrm{~m}^{-3}$. Mass-balance data for July 1st glacier in 1975 and 1985

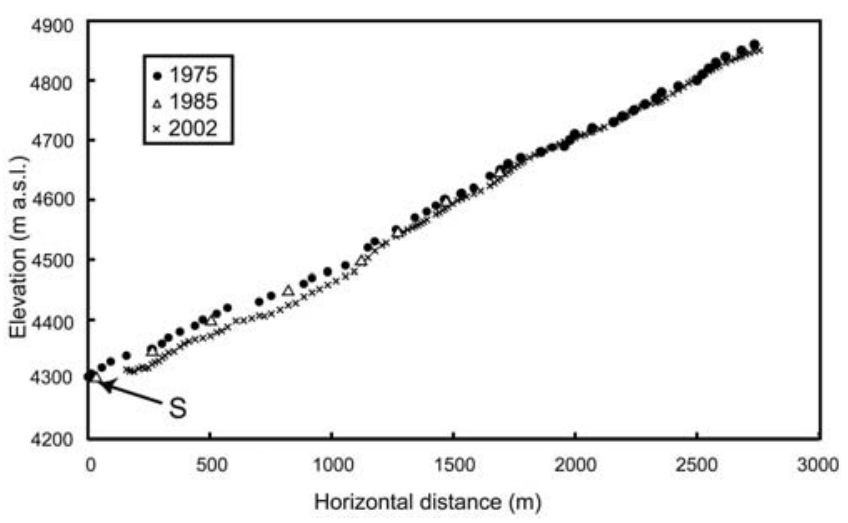

Fig. 5. Longitudinal cross-sections of July 1 st glacier surface profiles in 1975, 1985 and 2002. No surface elevation data from higher than $4650 \mathrm{~m}$ a.s.l. were available in 1985 . Horizontal distance 0 was set at the terminus in 1975, located at site S in Figure 3.

from Dyurgerov (2002) have also been included, based on the surface lowering data for those two years. The mass balances started to decrease toward the end of the 1970 s.

\section{DISCUSSION}

\section{Surface lowering}

The surface elevation change $(L)$ of a portion of the glacier is calculated using the emergence velocity $(E)$ and mass balance $(B)$ of the glacier,

$$
L=E+B \text {. }
$$

The mass balance is evaluated using the accumulation $(S)$ and ablation $(M)$ on the glacier,

$$
B=S-M \text {. }
$$

Units of all elements are in $\mathrm{ma}^{-1}$.

Average surface-elevation changes up to $1100 \mathrm{~m}$ from the terminus for the periods 1975-85 and 1986-2002 are shown in Table 1. We can evaluate the climate-change impact on the glacier mass balance by distinguishing the redistribution of the glacier ice caused by glacier dynamics from the surface elevation change.

\section{Emergence velocity}

The ice velocity averaged over the depth $(h)$ is taken to be $80 \%$ of the surface velocity $\left(u_{\mathrm{s}}\right)$ by assuming that the ice flow is laminar, that there is no basal motion (consistent with the glacier being of the polar type) and that the empirical constant ( $n$ ) in Glen's law is 3 (Paterson, 1994). The ice flux

Table 1. Average surface elevation change, emergence velocity, accumulation, precipitation and surface melt rate (all in $\mathrm{ma}^{-1}$ ) at the lower part of the glacier, 1975-85 and 1986-2002. Differences between the periods are also shown

\begin{tabular}{lccccc}
\hline Period & $\begin{array}{c}\text { Surface } \\
\text { elevation } \\
\text { change }\end{array}$ & $\begin{array}{c}\text { Emergence } \\
\text { velocity }\end{array}$ & $\begin{array}{c}\text { Snow } \\
\text { accumulation }\end{array}$ & Precipitation & $\begin{array}{c}\text { Melt } \\
\text { rate }\end{array}$ \\
\hline $1975-85$ & -0.50 & 0.43 & 0.15 & 0.41 & 1.08 \\
$1986-2002$ & -1.03 & 0.32 & 0.15 & 0.42 & 1.5 \\
Difference & -0.53 & -0.11 & 0.00 & 0.01 & 0.42 \\
\hline
\end{tabular}




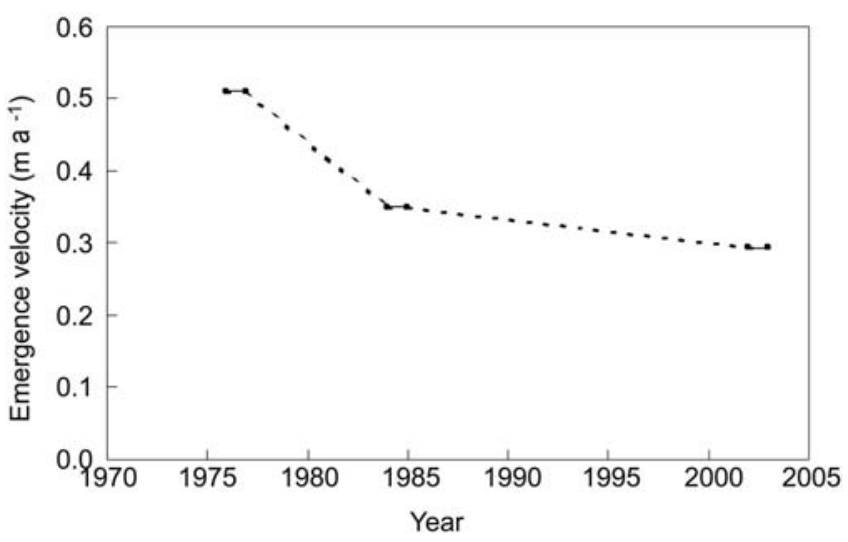

Fig. 6. Fluctuation in average emergence velocity from the terminus to $1100 \mathrm{~m}$ from the terminus.

from the upper part of the glacier through a cross-section can then be calculated as

$$
Q=\int_{0}^{w} 0.8 u_{\mathrm{s}} h \mathrm{~d} x,
$$

where $Q$ is ice flux through a cross-section and $w$ is glacier width at a cross-section.

The glacier depth distribution was measured by $\mathrm{Su}$ in 1977 (Su, 1985). The cross-section of the glacier in 2002 can be estimated assuming the bottom shape of the glacier had not changed and the surface lowering was uniform at the cross-section. The average emergence velocity of the lower part of the glacier can then be calculated as

$$
v=Q / S_{i},
$$

where $v$ is average emergence velocity over the lower part of the glacier, and $S_{\mathrm{i}}$ is the surface area of the lower part of the glacier.

The ice flux from the upper part of the glacier at the crosssection $1100 \mathrm{~m}$ from the glacier terminus can then be calculated from Equations (1) and (2) using the observed surface velocity and cross-section. The lower part of Figure 6 shows the variation in the average emergence velocity. This figure indicates that the ice flux from the upper to the lower part of the glacier has decreased, and that a relatively large reduction of the emergence velocity had occurred between 1975 and 1985. Accordingly, the average emergence velocity from 1975 to 1985 was $0.43 \mathrm{~m} \mathrm{a}^{-1}$, and that from 1986 to 2002 was $0.32 \mathrm{~m} \mathrm{a}^{-1}$, as shown in Table 1. Thus a decrease in emergence velocity of $0.11 \mathrm{ma}^{-1}$ would be expected to cause thinning of the ice.

\section{Glacier mass balance}

Air-temperature and precipitation data from the US National Climatic Data Center (NCDC) since 1955 were analyzed to clarify the cause of the mass-balance variations described above. The stations selected were limited to those near July 1 st glacier $\left(35-40^{\circ} \mathrm{N}, 94-104^{\circ} \mathrm{E}\right)$. Unfortunately, there were no NCDC air-temperature data available for certain years, including the period 1991-93. Therefore, air-temperature data since 1975 from the US National Centers for Environmental Prediction/US National Center for Atmospheric Research (NCEP/NCAR), produced by the US National Weather Service, were also analyzed.

On Asian glaciers, ablation and accumulation occur simultaneously during the summer monsoon period. The
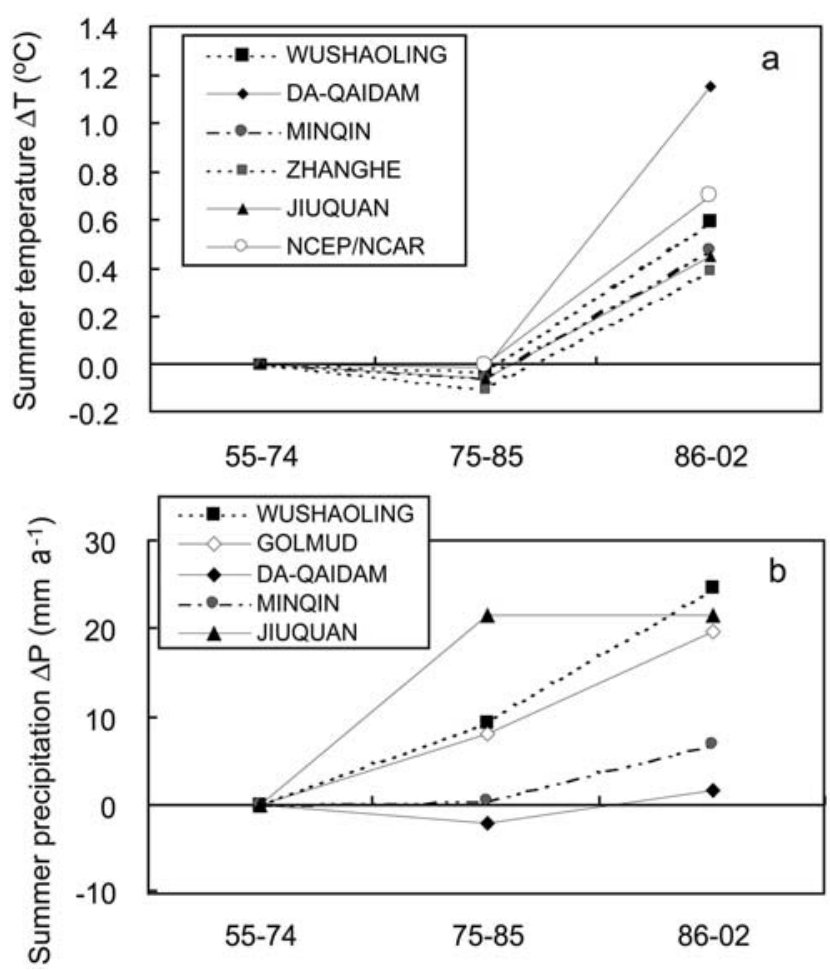

Fig. 7. Increasing values of summer (June-September) temperature (a) and precipitation (b), averaged over the periods 1975-85 and 1986-2002, since 1955-74. NCEP/NCAR temperature data were used in the analysis after 1975 .

glacier mass balance is therefore particularly sensitive to summer meteorological conditions. Accordingly, meteorological data from June to September (summer) were analyzed. Summer air-temperature and precipitation data at each station were averaged for the periods 1955-74, 1975-84 and 1985-2002. The differences from the 1955-74 average value are shown in Figure 7. Summer temperature from 1955-1974 to 1975-1984 decreased slightly, whereas from 1975-84 to 1985-2002 it increased sharply at all sites. Summer precipitation decreased at only one station between 1955-74 and 1975-85, while all sites showed large increases over the total study period.

Precipitation is in the form of snow (solid) or rain (liquid), depending on the air temperature during summer in this high Asian region. Thus, solid precipitation can be calculated from air-temperature and precipitation data. The relation between the solid precipitation ratio and air temperature was established by Ding and Kang (1985), who reported that $100 \%$ of solid precipitation occurs below $0^{\circ} \mathrm{C}$, and $50 \%$ at $3.5^{\circ} \mathrm{C}$, with all precipitation becoming liquid at $7^{\circ} \mathrm{C}$. Precipitation data from Wushaoling (3040 ma.s.l.) were analyzed to estimate the precipitation at July 1 st glacier (the annual precipitation at Wushaoling is on the same order as that observed at July 1 st glacier from 2002 to 2004 , and the altitude is similar to that of July 1 st glacier). Monthly precipitation values at July 1 st glacier were $72 \%$ of those at Wushaoling from 2002 to 2004. Thus, monthly precipitation data at July 1 st glacier were estimated based on the above relation, assuming that the altitudinal distribution of precipitation was constant on the glacier.

Temperature data at July 1 st glacier were estimated from the temperature data at $500 \mathrm{hPa}$ altitude (NCEP/NCAR), assuming a temperature lapse rate of $-0.82^{\circ} \mathrm{C}(100 \mathrm{~m})^{-1}$. The 
temperature lapse rate was deduced from the averaged temperature lapse rate between the observed air temperature at July $1 \mathrm{st}$ glacier at $4295 \mathrm{~m}$ a.s.l. and the temperature data at $500 \mathrm{hPa}$ with geopotential height from 2002 to 2004 .

Solid precipitation was calculated from the monthly precipitation data estimated from Wushaoling and the NCEP/NCAR re-analyzed temperature data at intervals of $100 \mathrm{~m}$ altitude. Moreover, precipitation has been averaged for the entire lower portion of the glacier area. Our results show that the average annual precipitation has increased by $0.01 \mathrm{~m} \mathrm{a}^{-1}$ from $1975 / 85$ to $1986 / 2002$, while the solid precipitation has changed $<1 \mathrm{~mm} \mathrm{a}^{-1}$ due to the increasing temperature indicated in Figure 7.

Surface elevation change, emergence velocity and accumulation are also summarized in Table 1 . The surface melt rate can then be evaluated from Equations (1) and (2) using emergence velocity, snow accumulation and surface elevation change. Results of this analysis indicate that mean snow accumulation has been almost constant since 1975, while the melt rate has increased by $0.42 \mathrm{~m} \mathrm{a}^{-1}$ from $1975-85$ to 1986-2002. Therefore, increased melt rate is considered to underlie the recent accelerated glacier surface lowering of July 1 st glacier.

The 1975-85 average melt rate was $1.08 \mathrm{~m} \mathrm{a}^{-1}$, and the positive cumulative temperature at $4400 \mathrm{~m}$ a.s.l. (the middle altitude of the lower part of the glacier) was 248 degreedays, obtained from the re-analyzed temperature data. Therefore, the degree-day factor was $4.4 \mathrm{~mm}^{\circ} \mathrm{C}^{-1} \mathrm{~d}^{-1}$ over this period. On the other hand, the positive cumulative temperature at $4400 \mathrm{~m}$ a.s.l. was 301 degree-days from 1986 to 2002. Therefore, the melt rate can be calculated as $1.32 \mathrm{~m} \mathrm{a}^{-1}$ from the degree-day factor of $4.4 \mathrm{~mm}^{\circ} \mathrm{C}^{-1} \mathrm{~d}^{-1}$ and the positive cumulative temperature of 301 degree-days. This is similar to the measured melt rate, which was $1.50 \mathrm{~m} \mathrm{a}^{-1}$ over this period. Thus, it can be quantitatively clarified that the recent melt rate has accelerated as a result of the increasing temperature.

Cao (1998) indicated that three glaciers in the Tien Shan, which are west of the Qilian Shan, shrank abruptly in the mid-1970s. This was attributed to a summer temperature rise, which caused an increase in melt rate and a decrease in annual snowfall. In the Qilian Shan, there was a melt-rate increase but not a snowfall decrease.

Discharge from the glacier basin $\left(3.8 \mathrm{~km}^{2}\right)$ including the glacier (shown in Fig. 3) can be calculated from the change in glacier area, total surface lowering and total precipitation, assuming that the altitudinal distribution of the precipitation remains constant. Figure 8 shows the net surface lowering and net precipitation in the basin from 1975 to 1985 and from 1986 to 2002, the combination of which represents discharges; the figure indicates that surface lowering has increased dramatically in recent decades. Average discharges from the basin during the periods 1975-85 and 1986-2002 were 0.45 and $0.68 \mathrm{~m} \mathrm{a}^{-1}$, respectively. Therefore, the total discharge from the glacier has increased about $50 \%$ between the two periods, largely as a result of glacier shrinkage.

\section{CONCLUSION}

July 1st glacier decreased in area by 5\% from 1956 to 2002 and by $4 \%$ from 1985 to 2002 . The surface lowering rates of the glacier surface were $0.06 \mathrm{ma}^{-1}$ for $1975-85$, and $0.38 \mathrm{~m} \mathrm{a}^{-1}$ for $1985-2002$. Thus, the glacier shrinkage rate

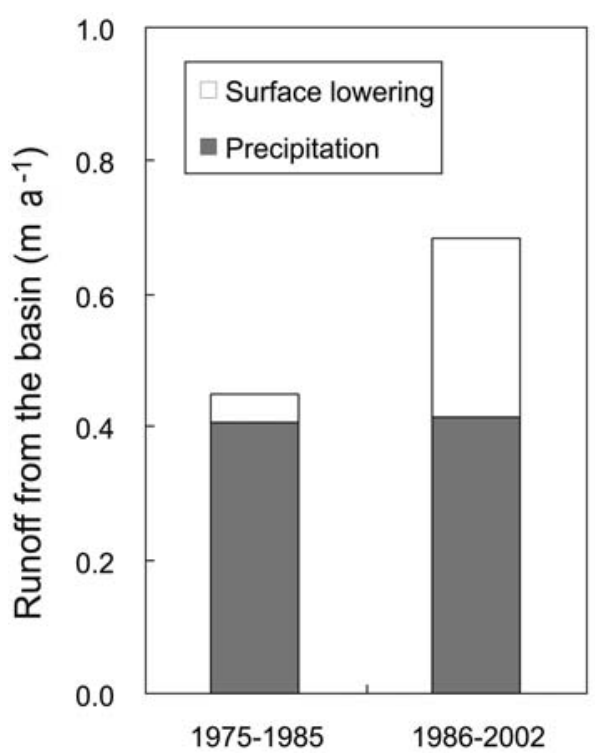

Fig. 8. Average runoff from July 1st glacier, 1975-85 and 19862002. Elements of the runoff (surface lowering and precipitation) are also shown.

has accelerated over the past 17 years. Such acceleration can be attributed to the temperature increase, based on our analysis of meteorological data.

Surface-elevation changes result from changes in emergence velocity, accumulation and surface melting. The contributions of these elements to surface lowering have been evaluated over the lower part of July 1 st glacier, where the lowering was most pronounced. Emergence velocities were calculated from our observations of surface velocity, ice thickness and glacier width. Accumulation (solid precipitation) was calculated from precipitation data near the glacier and re-analyzed NCEP/NCAR temperature data. The surface melt rate was obtained from the residual value of the surface elevation changes, emergence velocity and accumulation. Evaluation of the relation between climate change and mass balance indicated that changes in the accumulation rate and melt rate between the periods 197585 and 1986-2002 were +0.01 and $+0.4 \mathrm{~m} \mathrm{a}^{-1}$, respectively. The increasing surface melt rate, therefore, was the major cause of the recent acceleration in glacier shrinkage. Furthermore, the melting rates for the two periods estimated by the degree-day method coincided with the evaluated melt rate derived from emergence velocity, accumulation and surface lowering, thus confirming that the recent acceleration in glacier shrinkage was caused by increasing temperature. Finally, meltwater discharge from the glacier basin was calculated from surface lowering and precipitation taking into account the glacier area change. Because of glacier shrinkage, calculated discharge from the glacier has increased over the past 17 years by $>50 \%$ over the average value for the period 1975-85.

\section{ACKNOWLEDGEMENTS}

We thank the members of the Oasis Project (Historical evolution of adaptability to water resource changes in an oasis region) for valuable advice and logistic support in the field. This is a contribution to the Oasis Project, being promoted by the Research Institute for Humanity and Nature 
(RIHN), which provided financial support in addition to that from the Japanese Government's Special Coordination Fund for the Promotion of Science and Technology, Grants-in-Aid for scientific research (No. 14209020) and the Sumitomo Foundation. We also thank the Scientific Editor, B. Hubbard, and two anonymous referees whose suggestions greatly improved the paper.

\section{REFERENCES}

Babkin, V.I. and R.K. Klige. 2003. The contemporary hydrosphere. In Shiklomanov, I.A. and J.C. Rodda, eds. World water resources at the beginning of the twenty-first century. Cambridge, etc., Cambridge University Press, 13-16.

Braithwaite, R.J. and S.C.B. Raper. 2002. Glaciers and their contribution to sea level change. Phys. Chem. Earth, 27(3234), 1445-1454.

Braithwaite, R.J. and Y. Zhang. 1999. Relationships between interannual variability of glacier mass balance and climate. J. Glaciol., 45(151), 456-462.

Cao, M.S. 1998. Detection of abrupt changes in glacier mass balance in the Tien Shan Mountains. J. Glaciol., 44(147), 352-358.

Church, J.A. and 7 others. 2001. Changes in sea level. In Houghton, J.T. and 7 others, eds. Climate change 2001: the scientific basis. Contribution of Working Group I to the Third Assessment Report of the Intergovernmental Panel on Climate Change. Cambridge, etc., Cambridge University Press, 639-693.

Ding, L. and X. Kang. 1985. [Climatic conditions for the development of glaciers and their effect on the characteristics of glaciers in Qilian Mountains.] Mem. Lanzhou Inst. Glaciol. Geocryol., Academica Sinica, 5, 9-15. [In Chinese.]

Dyurgerov, M. 2002. Glacier mass balance and regime: data of measurements and analysis. Boulder, CO, University of Colorado. Institute of Arctic and Alpine Research. (INSTAAR Occasional Paper 55.)

Fountain, A.G. and W. Tangborn. 1985. The effects of glaciers on streamflow variations. Water Resour. Res., 21(4), 579-586.

Fujita, K. and Y. Ageta. 2000. Effect of summer accumulation on glacier mass balance on the Tibetan Plateau revealed by massbalance model. J. Glaciol., 46(153), 244-252.

Fujita, K., K. Seko, Y. Ageta, P. Jianchen and Y. Tandong. 1996. Superimposed ice in glacier mass balance on the Tibetan Plateau. J. Glaciol., 42(142), 454-460.

Haeberli, W., M. Hoelzle and S. Suter, eds. 1998. Into the second century of worldwide glacier monitoring: prospects and strategies. Paris, UNESCO Publishing. (Studies and Reports in Hydrology 56.)

Huang, M. 1990. On the temperature distribution of glaciers in China. J. Glaciol., 36(123), 210-216.

Khromova, T.E., M.B. Dyurgerov and R.G. Barry. 2003. Latetwentieth century changes in glacier extent in the Ak-shirak Range, Central Asia, determined from historical data and ASTER imagery. Geophys. Res. Lett., 30(16), 1863. (10.1029/ 2003GL017233.)
Liu, C., Y. Song and M. Jin. 1992. [Recent change and trend prediction of glaciers in Qilian mountain.] Mem. Lanzhou Inst. Glaciol. Geocryol., Academica Sinica, 7, 1-9. [In Chinese with English summary.]

Liu, S., W. Sun, Y. Shen and G. Li. 2003. Glacier changes since the Little Ice Age maximum in the western Qilian Shan, northwest China, and consequences of glacier runoff for water supply. J. Glaciol., 49(164), 117-124.

Meier, M.F. 1984. Contribution of small glaciers to global sea level. Science, 226(4681), 1418-1421.

Paterson, W.S.B. 1994. The physics of glaciers. Third edition. Oxford, etc., Elsevier.

Pelto, M.S. 1987. Mass balance of North Cascade glaciers and climatic implications. International Association of Hydrological Sciences Publication 168 (Symposium at Vancouver 1987 - The Influence of Climate Change and Climatic Variability on the Hydrologic Regime and Water Resources), 163-171.

Shi, Y., M. Huang and B. Ren. 1988. An introduction to the glaciers in China. Beijing, Chinese Academy of Science Press.

Song, G., C. Liu and M. Jin. 1992. [Surface movement velocity of the Qiyi glacier in Qilian mountain.] Mem. Lanzhou Inst. Glaciol. Geocryol., Academica Sinica, 7, 40-44. [In Chinese with English summary.]

Su, Z. 1985. [Thickness measurement of 'July 1st' Glacier in Qilian Mountains and some problems in glacier measurement by gravimetric method.] Mem. Lanzhou Inst. Glaciol. Cryopedol., Academica Sinica, 5, 16-21. [In Chinese.]

Sun, Z. and M. Huang. 1985. [The general features of glacier motion in Qilian Shan.] Mem. Lanzhou Inst. Glaciol. Cryopedol., Academica Sinica, 5, 61-72. [In Chinese.]

Tsvetkov, D.G., G.B. Osipova, X. Zichu, W. Zhongtai, Y. Ageta and P. Baast. 1998. Glaciers in Asia. In Haeberli, W., M. Hoelzle and S. Suter, eds. Into the second century of worldwide glacier monitoring: prospects and strategies. Paris, UNESCO Publishing, 177-196. (Studies and Reports in Hydrology 56.)

Wang, G. and G.D. Cheng. 1999. Water resources development and its influence on the environment in arid areas of China - the case of the Hei River basin. J. Arid Environ., 43, 121-131.

Warrick, R.A. and J. Oerlemans. 1990. Sea level rise. In Houghton, J.T., G.J. Jenkins and J.J. Ephraums, eds. Climate change: the IPCC scientific assessment. Cambridge, Cambridge University Press, 257-281.

Xie, Z., G. Wu, L. Wang and Z. Wang. 1985a. [Ice formation of glaciers in Qilian Shan.] Mem. Lanzhou Inst. Glaciol. Cryopedol., Academica Sinica, 5, 27-40. [In Chinese.]

Xie, Z., G. Wu and L. Wang. 1985b. [Recent advance and retreat of glaciers in Qilian Shan.] Mem. Lanzhou Inst. Glaciol. Cryopedol., Academica Sinica, 5, 82-90. [In Chinese.]

Yamaguchi, S. 2003. Daily fluctuations in flow of temperate glaciers and their application to a glacier model. (Doctoral thesis, Hokkaido University.)

Zhu, S. and Q. Wang. 1996. [Temporal-spatial distributions and recent changes of precipitation in the northern slopes of the Qilian Shan]. Journal of Glaciology and Geocryology, 18, 296304. [In Chinese.] 